\title{
DROPOUT IN AN ONLINE TRAINING FOR TRAINEE TEACHERS
}

\author{
KlausD.Stiller[klaus.stiller@ur.de],Department of Educational Science, \\ Regine Bachmaier[regine.bachmaie@@ur.de],Computer Centre,University of Regensburg, Germany
}

\begin{abstract}
High dropout rates are still a problem with online training. It is strongly suggested that learner characteristics influence the decision to persist in an online course or to drop out. The study explored the differences in domain-specific prior knowledge, motivation, computer attitude, computer anxiety, and learning skills between dropouts and active learners who enrolled in a vocational online training about media pedagogy for teachers. The data were collected from 575 trainee teachers from which three groups were formed: (a) students who only registered $(n=72)$ and (b) students who started learning but failed to complete any of the course modules ( $\mathrm{n}=124)$ and (c) active students who completed at least one module $(\mathrm{n}=379)$. A dropout rate of $34.1 \%$ was observed. In general, only small effects were found. Students dropping out were older, had less prior knowledge, and lower skills in arranging an adequate learning environment.
\end{abstract}

\section{Abstract in German}

Hohe Abbruchquoten bei Onlinekursen sind immer noch ein Problem. Es wird angenommen, dass Entscheidungen von Lernenden aus einem Kurs auszusteigen oder weiterzumachen wesentlich von ihren Eigenschaften abhängen. Im Rahmen eines skriptbasierten Onlinekurses zur Medienpädagogik für Lehrer wurde untersucht, inwiefern sich Kursabbrecher von Absolventen bezüglich Vorwissen, Lernmotivation, Einstellung zum Computer, Computerängstlichkeit sowie drei Lernstrategien selbstregulierten Lernens (metakognitive Strategien, Zeitmanagement, Strategien zur Gestaltung einer adäquaten Lernumgebung) unterscheiden. Am Onlinekurs nahmen 575 Referendare teil, wovon sich 72 lediglich für den Kurs anmeldeten und 124 mit dem Lernen begannen, aber keine Kurseinheiten abgeschlossen haben (Dropout Rate von 34.1\%). Diese Dropout-Gruppen wurden mit einer aktiven Lernergruppe verglichen, welche wenigstens eines von acht Kursmodulen vollständig bearbeitet hatte. Im Vergleich der Gruppen zeigten sich kleine Effekte. Kursabbrecher waren älter, hatten weniger Vorwissen und niedrigere Fähigkeiten im Arrangieren einer adäquaten Lernumgebung.

Keywords: dropout, online learning, adult learning, trainee teachers, learner characteristics

\section{Introduction}

Online learning has become an established method of learning alongside the traditional ways of learning and teaching (e.g., Allen \& Seeman, 2016), but high dropout rates are a persistent problem (e.g., Lee \& Choi, 2011). In addition to features of an online training course and the learning conditions, research suggests that learner characteristics influence the decision to persist or dropout from an online course (e.g., Lee \& Choi, 2011). Therefore, we explored in the current study differences between learners dropping out at various stages from an online training for trainee teachers and successful learners in domain-specific prior knowledge, motivation, computer attitude, computer anxiety, and learning skills. The investigation was conducted against the background of the multidimensional learning tasks model (Tyler-Smith, 2006). 


\section{Dropout and the multidimensional learning tasks model}

Online student dropout has been described and analysed in the context of whole study programs (e.g., Grau-Valldosera \& Minguillón, 2014) and single online courses (e.g., Lee \& Choi, 2011). It appears to be a complex phenomenon depending on a multitude of factors, including various learner characteristics (e.g., Lee \& Choi, 2011). Determinants of learner attrition and persistence with online training have been shaped in various models with different levels of complexity (e.g., Gazza \& Hunker, 2014; Kember, 1989; Lee \& Choi, 2011; Tinto, 1993). The multidimensional learning tasks model (MDLTM; Tylor-Smith, 2006) was developed for first-time online learners, but it can also be useful for any learner who is unfamiliar with the specific requirements of any course environment, especially when the learning method is a stand-alone online training with its own unique features.

The MDLTM proposes five tasks that learners must learn and manage to successfully engage in and complete an online course. Students must negotiate (a) the technology, (b) the Learner Management System interface, (c) the learner role, (d) the learning content, and (e) the computermediated communication (CMC) interaction. Tyler-Smith (2006) based his explanations of how these tasks contribute to early attrition in an online course on Cognitive Load Theory (CLT). CLT focuses on the limited capacity of working memory in learning and how it is burdened by useful und unnecessary cognitive processes, referred to in the literature as cognitive load (Sweller, 2010). The components of load are intrinsic, germane, and extraneous. Intrinsic load is created by task complexity; it is the basic amount of processing required for understanding a presentation. Germane load extends beyond understanding and is bound to processing information used to build schemas and for long-term memory stores. Extraneous load results from the presentation manner of the material and is often the main source that inhibits learning, because it is unrelated to the construction or automation of schemas. Successful learning occurs when working memory capacity is not overburdened by overall cognitive load and when as much capacity as is available can be dedicated to schema acquisition and automation, which creates germane load. Cognitive overload is mostly created by extraneous and intrinsic load.

The MDLTM focusses on the cognitive load imposed when solving the five tasks in an online course. When cognitive overload occurs, learners are more likely to drop out from the course. In the first task, negotiating the technology, the learner must cope with the range of technologies used in a course. This challenge might require learners to improve or acquire new skills, for example, learning how to install or configure hardware or software according to system requirements. The second task, negotiating the Learner Management System interface, requires the learner to build an adequate model of the course structure and navigation. The usability of an online course environment is suggested to be a very important aspect for a learner's success or failure in negotiation. The core element of the third task, negotiating the learner role, addresses the ability to adopt the role of learner to meet the requirements of an online course. For example, learners are often expected to be self-directed, motivated, and they are assumed to be physically isolated from instructors and other learners. If learners, however, fail to accept this role, they are more likely to become disengaged and drop out. Negotiating the learning content is the fourth task, which refers to the learning materials and didactics of an online course and is related to the ability to engage in and to master the required activities (with a particular focus on adequate cognitive processing) in the course. Learners' confidence and ability to manage the content might depend on their learning experience, domain-specific prior knowledge, and available learning strategies. The fifth task, negotiating CMC interaction, focusses on the synchronous and asynchronous channels of communication in an online course and is related to the ability to engage in and master the required communicative activities. Communication is often based on electronic text and special structures (e.g., discussion forums) that might not be familiar to all learners. The learner's confidence and ability to manage communication might depend on the 
learner's experience with special kinds of communication channels and available communication strategies.

\section{Student characteristics}

\section{Domain-specific prior knowledge}

Research on the basis of CLT has revealed expertise reversal effects in a variety of instructional designs (Kalyuga, 2014). Expertise reversal effect is a general term for all instructional design effects that are dependent on prior knowledge and result in a learning environment that is effective for learners with little prior knowledge but ineffective for learners with considerable prior knowledge. This effect has often been studied in less complex situations (e.g., learning with text and pictures), which has nowadays widened to learning with multiple representations. However, it has been rarely analysed in more complex situations such as online trainings. Kalyuga et al. (2003) suggested that instructions allowing learners to control the pace and sequence in which information is presented is more adequate for experienced learners. Self-paced and selfsequenced learning is a common feature of online learning courses, thus learning scenarios should be adequate for inexperienced as well as experienced learners. Viewed from the perspective of the MDLTM, more experienced learners are assumed to engage more adequately in negotiating the learning content. Intrinsic load is assumed to be influenced by prior knowledge. The more prior knowledge, the less intrinsic load might be experienced while learning, because prior knowledge reduces the complexity of the content. A higher level of prior knowledge is often also connected to a lower level of germane load because of having less new information connected to prior knowledge. As a result of this prior knowledge advantage, learners might experience less working memory load and be less threatened by cognitive overload. In contrast, the disadvantages of having less prior knowledge might influence a learner's decision to drop out when negotiating the learning content. In the context of complex learning environments, including online learning scenarios, the level of domain-specific prior knowledge is known to consistently influence program usage, information processing and performance (Amadieu, Tricot, \& Mariné, 2009). Studies from hypertext research have reported the positive impact of prior knowledge on various performance measures (e.g., Amadieu et al., 2009; McDonald \& Stevenson, 1998; Stiller, 2003, 2009, 2015b). However, non-significant correlations were found when the courses were aimed at mastery learning (e.g., Stiller \& Köster, manuscript submitted for publication).

\section{Intrinsic motivation}

Intrinsic motivation refers to performing a behaviour or activity because of its inherent interest or joy, whereas behaviour that is extrinsically motivated is performed because of external consequences (Ryan \& Deci, 2000). Intrinsic motivation is connected to high-quality learning (Ryan \& Deci, 2000), and it might affect dropout rates. A higher level of intrinsic motivation might counteract (over)load and thus contribute to reduced dropout rates. Students might not give up as easy as when they are less or extraneously motivated. From the perspective of MDLTM, motivation might play a role in all five tasks, especially in reference to overcoming obstacles. Motivation might influence experienced load and how students manage it especially when load is high. Motivation is one of the most frequently studied covariates of dropout, and numerous studies have shown it to be correlated with course persistence and dropout (e.g., Castles, 2004; Chyung, 2001; Grau-Valldosera \& Minguillon, 2014; Hart, 2012; Hartnett, St. George, \& Drone, 2011; Ivankova \& Stick, 2007; Osborn, 2001; Park \& Choi, 2009; Parker, 2003). 


\section{Computer attitudes}

Attitudes consist of affective, conative and cognitive components (Richter, Naumann, \& Horz, 2010). From a cognitive perspective, attitudes are often defined as beliefs that are organized in topics, hence the computer as a self-experienced instrument for working and learning might be of interest concerning dropout (Richter et al., 2010). Computer attitude might influence a learner's decision to drop out by affecting working memory load. Negative computer attitudes might engender a more extraneous load because of, for example, disturbing thoughts about the computer malfunctioning or even crashing, particularly when negotiating both the technology and the Learner Management System interface and while learning. The increased extraneous load could initiate a dropout decision. In contrast, learners with positive attitudes should be less prone to such negative thoughts and thus less likely to suffer from extra working memory load by taskforeign cognitions. Consequently, these learners are assumed to engage adequately in negotiating technology and the system interface and in information processing and knowledge construction. Only a few studies have been conducted on the effects of computer attitudes on learning performance. Stiller $(2009 ; 2015 \mathrm{a})$ found negative effects of negative attitudes and interaction effects with information presentation and navigation. Positive effects of positive attitudes (e.g., attitudes towards e-learning, internet use, information technology, and technology use) have also been reported on course usage and persistence (Bernard et al., 2004; Stiller \& Köster, 2016).

\section{Computer anxiety}

Similar to the relationship between computer attitudes and online learning, computer anxiety might also influence learning in an online environment by affecting working memory load. Computer anxiety is considered to be a trait, which comprises cognitive and affective components such as feelings of anxiety and worrisome thoughts (Richter et al., 2010). Computer anxiety might contribute more extraneous load because of intervening negative emotions and negative thoughts about the computer, which in turn could make the option of dropping out more attractive. Learners without computer anxiety are expected to adequately engage in negotiating the technology and the Learner Management System interface and engage in information processing and knowledge construction, because their working memory will be less burdened. To date, most studies have focused on the relationships between anxiety, computer self-efficacy, and performance or learning system usage (also computer usage), mostly assuming that anxiety has only an indirect negative effect on performance and course usage but a direct influence on self-efficacy, which directly influences performance and course usage (Hauser, Paul, \& Bradley, 2012; Saadé \& Kira, 2009; Sam, Othman, \& Nordin, 2005). Few studies have investigated computer anxiety and course dropout or course persistence (e.g., Long et al., 2009; Stiller \& Köster, 2016). Long et al. (2009) reported no differences between the employees from a Midwest-based landscaping company in the U.S. who completed an online course and those who dropped out. Stiller and Köster (2016) reported that dropout employees had a higher level of computer anxiety than successful learners.

\section{Learning strategies}

Bringing cognitive, metacognitive, motivational and behavioural skills into action and using them adequately are thought to be the core of competent learning (Friedrich \& Mandl, 1992). In general, learning strategies are defined as activities that learners apply to augment or facilitate the perceiving, processing and storing of information (Friedrich \& Mandl, 1992). These strategies are thought to monitor, control and regulate basic processes such as the decoding of words and images or eye movement (Weinstein \& Mayer, 1986). Pintrich (1999) also differentiates between cognitive learning strategies, metacognitive learning strategies and resource management strategies. The metacognitive strategies, time management and creating a supporting learning environment, are considered to be particularly relevant for online learning. Metacognitive 
strategies include planning, monitoring and the regulation of cognitive processes (Pintrich, 1999). These strategies serve the purpose of planning suitable procedures (choice of strategies), monitoring (correcting the execution of strategies) and evaluating the result (achievement of goals and objectives) as well as regulating (interventions for corrections) the procedural flow. A successful use of metacognitive strategies is based on the knowledge about learning strategies and their adequate application conditions. Resource management strategies are self-management strategies that support learning in general, shielding against external disturbances and influences of all kind (Friedrich \& Mandl, 1992). The strategies of time management and learning environment belong to this category. They focus on the organization of learning activities. Strategies of learning environment are about creating a learning environment that supports learning. Time management is about adequately assigning appropriate time periods for learning. The competent use of time management and learning environment strategies might reduce cognitive load while learning and thus prevent cognitive overload. It might particularly reduce extraneous load (being able to assign time to learning without disturbances) and foster learning (being able to focus cognitive resources on information processing more efficiently), which in turn might contribute to reducing dropout. Research has shown that management skills are significant predictors of dropout (Lee, Choi, \& Kim, 2013), especially managing time effectively (Hart, 2012; Holder, 2007; Ivankova \& Stick, 2007; Lee \& Choi, 2011; Osborn, 2001; Shin \& Kim, 1999; but not Lee, Choi, \& Kim, 2013), and having comfortable conditions for studying (Castles, 2004; Osborn, 2001; Shin \& Kim, 1999; but not Lee, Choi, \& Kim, 2013) correlated with dropout.

\section{Research objectives and expectations}

An online training in media pedagogy for teachers was used to explore learner attrition. We first identified groups of learners according to the extent that they completed the training and recorded dropout rates. We then examined whether learner attrition is influenced by prior knowledge, intrinsic motivation, computer attitude, computer anxiety and learning strategies by comparing the learner characteristics between the group of learners who dropped out and the group of successful learners. We assumed that dropout would be more likely when a learner has a lower level of prior knowledge, intrinsic motivation and learning skills, and more negative attitudes towards computers and a higher level of computer anxiety.

\section{Method}

\section{Participants}

The data was collected from the trainee teachers who registered for the advanced online training, "Media Pedagogy for Teachers". The training was authorized by and offered throughout the German Federal State of Bavaria. The training contributes to the field of continuing vocational education and training on media pedagogy and addresses teachers of primary schools (Grundschule), secondary general schools (Hauptschule), intermediate schools (Realschule) and grammar schools (Gymnasium) in the German Federal State of Bavaria (see Federal Ministry of Education and Research, 2016 for details on German classification of schools). Students were recruited by promoting the online training offline via flyers that were placed at these types of schools throughout Bavaria. In-service teachers and teachers from other school types participated in the training, but only the group of trainee teachers was analysed. Participants are described in the results section.

\section{Description of the online training}

The training was offered only online without a fixed schedule. The content was presented in modules, and the teaching was based on instructional texts. According to action- and problem- 
oriented didactics, the training was constructed around four of the five design principles of problem-based learning environments (Reinmann \& Mandl, 2006): learning situated in authentic problems; using multiple contexts for learning; using multiple perspectives for learning; learning with instructional support; and learning in a social context. The latter principle was excluded, because it was not expected to guarantee a high level of flexibility for the learners. In addition, the structure of each module was modelled on the Nine Events of Instruction (Gagné et al., 1992). The nine events are (a) gain attention, (b) inform about objectives, (c) stimulate recall of prior knowledge, (d) present the material to be learned, (e) provide guidance for learning, (f) elicit performance, $(\mathrm{g})$ provide informative feedback, $(\mathrm{h})$ assess performance and (i) enhance retention and transfer. When developing the design of the learning environment and the instructional materials, we paid attention to providing a motivating stimulating learning environment (Keller \& Koop, 1987), a high level of self-instruction (Tomei, 2007) and an effective and efficient information presentation (Sweller, 2010).

The training consists of eight modules organized in two blocks. Media education: (a) typical everyday life of children and adolescents, (b) Where to find what in the Web - useful web search, (c) Web 2.0 - the participatory web, and (d) Risks and dangers for children and adolescents on the web; Media didactics: (a) WebQuests - a method of pupil centred learning by using the web, (b) Generation SMS - the use of mobile phones by children and adolescents, (c) Reading, what else! - reading as a key to media literacy, and (d) How to find a good learning program - evaluation criteria for educational software. Students who completed at least one of the eight modules successfully could request a training certificate listing all successfully completed modules. A successful completion of any module was calculated with a workload of 60 to 90 minutes, which sums to 8 to 12 hours to complete all of the modules. In addition, an introductory module informs about content, technical requirements, course organization and self-management for successful online learning. Registration and participation was free.

The starting point of the online training was a Moodle course portal (Version 1.9.2). After registering and logging in for the first time, an introductory module was presented. Then students could freely decide how many of the modules they wanted to study and in which sequence. Each training module had a linear structure represented by six screen pages: (a) module profile, (b) case example, (c) test of domain-specific prior knowledge, (d) instructional unit, (e) module evaluation, and ( $\mathrm{f}$ ) final module test. The module profile provided an overview of the content and the teaching objectives. The case example represented a real life problem with the purpose of engaging students. A test of prior-knowledge without a time limit was used for activating students' prior knowledge and for giving feedback about their level. The instructional unit comprised an obligatory instructional text and optional supporting material, for example, links to videos, audios, webpages, and literature that could be used for further elaboration. The module evaluation provided a questionnaire that assessed various aspects of the module studied, for example, content difficulty, ease of learning, and satisfaction with modules. The final module tests consisted of 15 multiple-choice items that evaluated factual knowledge learned in the training, the result of which was provided as feedback to the student. Learners were required to answer at least $50 \%$ of the items correctly to have successfully completed a module. Otherwise, the student's performance on the module was recorded as completed but failed. The aim of the training was to provide factual knowledge. Thus, multiple-choice tests were an appropriate instrument for measuring learning success.

Support for students was provided via e-mail, online chat or phone for questions about content or difficulties in understanding an issue, including giving assistance with organization and technology. Response to e-mail was normally delivered within a few hours without exception for weekends and nights, and chat and phone consulting were provided during assigned office hours in the afternoon and on Saturday. Office hours were announced at least four weeks in advance. 


\section{Procedure and means of measurements}

The training was offered from October 2009 to July 2010, which was during the regular German school year. Anyone interested in the course could register by specifying a name, username, and password. After registration was completed, the students' first login directed them to the introductory module. Before starting the training, participants were asked to complete the first online questionnaire that gathered demographic information and assessed various learner characteristics. Tables A and B of the appendix list the items of the used measurement scales. After completing the first questionnaire, the eight course modules were accessible. A priorknowledge test was presented at the beginning of each module. After studying the module, participants completed a final module test. A student could provide up to eight prior knowledge scores, one for each module.

The teachers' motivation to participate in the online training was assessed with the Interest/Enjoyment scale of the Intrinsic Motivation Inventory (Ryan, 1982). Their attitude towards computers was examined, focusing on the personal experience with using the computer as a means for learning and working. The negative component in the sense of the computer being regarded as an uncontrollable machine was measured by the subscale "Personal experience / learning and working / autonomous entity" of the Questionnaire for the Content-Specific Measurement of Attitudes toward the Computer (QCAAC; Richter et al., 2000; 2010). Subsequently, computer anxiety was examined by using the subscale "Confidence in dealing with computers and computer applications" of the QCAAC (Richter et al., 2010), which focuses on the cognitive and affective components. Additionally, the use of three exemplary persistent strategies of self-regulated learning were assessed as measures of learning competence: metacognitive learning strategies (planning, monitoring and regulating), time management and learning environment (see Questionnaire for Measuring Learning Strategies of Students by Wild and Schiefele (1994)). The domain specific prior-knowledge test at the beginning of each module was assessed with a 5-item multiple choice test. Each item comprised four answers of which at least one was correct.

Prior knowledge was scored as percent correct and a mean was calculated across the number of tests completed (from 1 to 8 possible scores). Means of items were calculated for all other scales. A high score of all measures expresses a higher level of the feature in focus except for computer attitude which indicates a low negative attitude.

Table 1: Means and standard deviations and the potential score range of each assessment

\begin{tabular}{lcccccc} 
& $\begin{array}{c}\text { Number of } \\
\text { items used in } \\
\text { each } \\
\text { assessment }\end{array}$ & $\begin{array}{c}\text { Number of } \\
\text { assessments } \\
\text { an individual } \\
\text { score is based } \\
\text { on }\end{array}$ & M & SD & Range & $\begin{array}{c}\text { Cronbach's } \\
\text { alpha }\end{array}$ \\
\hline Prior knowledge & 5 & 1 to 8 & 49.47 & 14.13 & $0-100$ & .08 to $.50^{* *}$ \\
Interest / Enjoyment & 7 & 1 & 3.91 & 0.62 & $1-5$ & .85 \\
Computer attitude & 9 & 1 & 3.98 & 0.72 & $1-5$ & .85 \\
Computer anxiety & 8 & 1 & 2.06 & 0.69 & $1-5$ & .82 \\
Metacog. strategies & 11 & 1 & 3.51 & 0.57 & $1-5$ & .78 \\
Time management & 4 & 1 & 2.63 & 0.97 & $1-5$ & .83 \\
Learning environment & 6 & 1 & 4.06 & 0.66 & $1-5$ & .77 \\
\hline Thange; Crongan
\end{tabular}

${ }^{(*)}$ Range; Cronbach's alpha was calculated as a reliability measure of internal consistency for each module 


\section{Results}

A total of 575 trainee teachers registered for the course and answered the first questionnaire (see Table 2). Two records contained missing age data. More female ( $72 \%)$ than male trainees $(28 \%)$ enrolled in the training. The mean age of trainees was 27.25 years $(\mathrm{SD}=.00$, range from 20 to 49 years, $\mathrm{n}=573)$. Most trainees worked in an intermediate school $(33 \%)$ and a specialised upper secondary or a grammar school (30\%), followed by primary school $(20 \%)$ and secondary general schools $(15 \%)$. Only $2 \%$ of trainees worked in other school types. The following groups of persistent and dropout learners could be identified:

1. First dropout group of absent students: Registered participants who completed none of the eight module prior-knowledge tests were called absent participants. They maximally took notice of the module profiles and case examples.

2. Second dropout group of viewing students: Registered participants completed at least one of the modules' prior knowledge tests, but never completed a module by finishing any of the final module tests were called viewing students. They had access to the instructional texts of the modules, but the extent that they claimed or even studied them is unknown.

3. Persisting group of studying students: Registered trainee teachers who completed at least one of the modules' final tests, successfully or not, were called studying students.

The dropout rates were calculated for the two dropout groups of registered trainee teachers. We found $12.5 \%$ absent and $21.6 \%$ viewing students, with a total rate of $34.1 \%$ dropouts. The studying students mostly started $(26 \%)$ and completed $(32 \%)$ one or two modules, or they started and completed all of the modules (56\% and 51\%). The viewing students mostly started only one or two modules (91\%), and they never completed one.

Table 2: Demographic characteristics of the registered trainee teachers, dropout and persistent groups

\begin{tabular}{llcccc} 
& Total & $\begin{array}{c}\text { No. (\%) of } \\
\text { registered } \\
\text { students }\end{array}$ & $\begin{array}{c}\text { No. (\%) of } \\
\text { absent } \\
\text { students }\end{array}$ & $\begin{array}{c}\text { No. (\%) of } \\
\text { viewing } \\
\text { students }\end{array}$ & $\begin{array}{c}\text { No. (\%) of } \\
\text { studying } \\
\text { students }\end{array}$ \\
\hline Sex & Female & $575(100.0)$ & $72(12.5)$ & $124(21.6)$ & $379(65.9)$ \\
\hline Type of & Male & $414(72.0)$ & $48(66.7)$ & $87(70.2)$ & $279(73.6)$ \\
school & Secondary general school & $161(28.0)$ & $24(33.3)$ & $37(29.8)$ & $100(26.4)$ \\
& Intermediate school & $117(20.3)$ & $13(18.1)$ & $20(16.1)$ & $84(22.2)$ \\
& Specialised upper & $190(33.0)$ & $22(30.6)$ & $33(26.6)$ & $135(35.6)$ \\
& secondary school / & $172(29.9)$ & $26(36.1)$ & $39(31.5)$ & $107(28.2)$ \\
& grammar school & & & & \\
& Other than listed & $9(1.6)$ & & $7(5.6)$ & $2(0.5)$ \\
\hline No. of & 0 & $72(12.5)$ & $72(100.0)$ & & \\
started & 1 & $154(26.8)$ & & $101(81.5)$ & $53(14.0)$ \\
modules & 2 & $58(10.1)$ & & $12(9.7)$ & $46(12.1)$ \\
& 3 & $29(5.0)$ & & $4(3.2)$ & $25(5.5)$ \\
& 4 & $17(3.0)$ & & $1(0.8)$ & $16(4.2)$ \\
& 5 & $8(1.4)$ & & $3(2.4)$ & $13(3.4)$ \\
& 6 & $16(2.8)$ & & & $6(1.6)$ \\
& 7 & $6(1.0)$ & & $3(2.4)$ & $212(55.9)$ \\
\hline
\end{tabular}




\begin{tabular}{|c|c|c|c|c|c|}
\hline \multirow{9}{*}{$\begin{array}{l}\text { No. of } \\
\text { successfully } \\
\text { completed } \\
\text { modules }\end{array}$} & 0 & $204(35.5)$ & \multirow[t]{9}{*}{$72(100.0)$} & \multirow[t]{9}{*}{$124(100.0)$} & $8(2.1)$ \\
\hline & 1 & $77(13.4)$ & & & $77(20.3)$ \\
\hline & 2 & $45(7.8)$ & & & 45 (11.9) \\
\hline & 3 & $15(2.6)$ & & & $15(4.0)$ \\
\hline & 4 & $17(3.0)$ & & & $17(4.5)$ \\
\hline & 5 & $10(1.7)$ & & & $10(2.6)$ \\
\hline & 6 & $7(1.2)$ & & & $7(1.8)$ \\
\hline & 7 & $6(1.0)$ & & & $6(1.6)$ \\
\hline & 8 & 194 (33.7) & & & 194 (51.2) \\
\hline
\end{tabular}

The one persistent group and two dropout groups were compared in reference to sex, age, type of school, and the learner characteristics of interest. Differences were found between the groups for type of school $\left(\lambda^{2}=25.41, \mathrm{df}=8, \mathrm{p}<.01\right)$ and age (see Table 3$)$ but not sex $\left(\lambda^{2}=1.71\right.$, $\mathrm{df}=2$, ns). Persisting students were on average more than one year younger than the other groups, and the viewing students were the oldest in the sample. Differences in type of school are because of the school type "other than listed". Trainee teachers of these schools were mainly found in the viewing group. A chi-square test on the main four categories of school types showed no significant differences in distribution $\left(\lambda^{2}=8.38, \mathrm{df}=6, \mathrm{~ns}\right)$. Finally, no differences were found between the groups on motivation, computer attitude and anxiety as well as meta-cognitive learning strategies and time management, but strategy use for creating an adequate learning environment was significantly smaller for viewing students. In addition, prior knowledge was smaller for the viewing students than for the studying students. Generally, only small effects were found.

Table 3: Means and standard deviations of the student groups, ANOVA results and effect sizes are shown

\begin{tabular}{lccccccc} 
& $\begin{array}{c}\text { Absent } \\
\text { students }\end{array}$ & $\begin{array}{c}\text { Viewing } \\
\text { students }\end{array}$ & $\begin{array}{c}\text { Studying } \\
\text { students }\end{array}$ & & & & \\
\hline Age & $\mathrm{M}(\mathrm{SD})$ & $\mathrm{M}(\mathrm{SD})$ & $\mathrm{M}(\mathrm{SD})$ & $\mathrm{F}$ & $\mathrm{df}_{1}, \mathrm{df}_{2}$ & $\mathrm{p}$ & $\mathrm{\eta}^{2}$ \\
\hline Prior knowledge & $27.86(4.48)$ & $28.81(5.27)$ & $26.62(3.19)$ & 15.68 & 2,570 & .01 & .05 \\
Intrinsic motivation & - & $47.16(17.66)$ & $50.23(12.70)$ & 4.42 & 1,501 & .04 & .01 \\
Computer attitude & $3.99(0.58)$ & $3.82(0.70)$ & $3.92(0.62)$ & 2.03 & 2,572 & $\mathrm{~ns}$ & .01 \\
Computer anxiety & $1.95(0.64)$ & $4.01(0.75)$ & $3.95(0.72)$ & 0.78 & 2,572 & $\mathrm{~ns}$ & .00 \\
Metacog. strategies & $3.49(0.58)$ & $2.00(0.69)$ & $2.09(0.70)$ & 1.24 & 2,572 & $\mathrm{~ns}$ & .00 \\
Time management & $2.59(1.03)$ & $2.56(0.64)$ & $3.54(0.54)$ & 1.26 & 2,572 & $\mathrm{~ns}$ & .00 \\
Learning environment & $4.14(0.62)$ & $3.89(0.74)$ & $2.66(0.96)$ & 0.52 & 2,572 & $\mathrm{~ns}$ & .00 \\
\hline
\end{tabular}

\section{Discussion}

We could identify various dropout groups by focusing on behavioural data at critical incidences in the training such as taking at least one prior knowledge test (or not) and taking at least one final module test (or not). Dropout and persisting groups showed differences on some psychological and other characteristics, but overall effects were small. Given that the aim of the training was to qualify trainee teachers, we defined the persisting group of students as trainees who studied modules. This categorization resulted in a dropout rate of $34.1 \%$, which is in the lower end of the range of dropout rates previously reported (Kranzow, 2013; Xenos et al., 2002). The characteristics of age, prior knowledge, intrinsic motivation, computer attitude, computer anxiety, and learning skills appeared to play different roles for the various dropout groups. Age, prior knowledge and skills in arranging one's learning environment showed little effects on dropping out, whereas intrinsic motivation, computer attitude, computer anxiety, metacognitive 
skills and time management had no effect. The upper mentioned characteristics are discussed in the following.

The dropout groups of absent and viewing students appeared to be older. In contrast to the literature, successful learners in this study appear to be younger than dropout students (cf. Yukselturk \& Bulut, 2007). One explanation for the age differences that emerged in this study is that the older trainee teachers might have been more involved in the second and final education year of teacher training, which typically comes with a higher work load and could thus contribute to dropping out. In contrast, starters in the practical phase of teacher education might have more resources to engage in other opportunities such as participating in media pedagogy training. Moreover, the dropout group of viewing students also had a lower level of prior knowledge and lower skills to arrange an adequate learning environment. This lack of knowledge and skills could be connected to a higher level of experienced load while studying, resulting in an inadequate studying experience that required more time needed to study the modules and consequently the inability to complete them. This is in line with former research about learning performance (Amadieu et al., 2009; McDonald \& Stevenson, 1998; Stiller, 2003; 2009; 2015b) and learning management skills (having comfortable conditions for studying; Castles, 2004; Osborn, 2001; Shin \& Kim, 1999). We found, however, that time management was not an essential factor in contrast to other studies (Hart, 2012; Holder, 2007; Ivankova \& Stick, 2007; Lee \& Choi, 2011; Osborn, 2001; Shin \& Kim, 1999). Motivation also did not appear to be a significant factor of dropping out, which is not consistent with results from intrinsic motivation studies (Castles, 2004; Chyung, 2001; Grau-Valldosera \& Minguillon, 2014; Hart, 2012; Ivankova \& Stick, 2007; Osborn, 2001; Park \& Choi, 2009; Parker, 2003).

Overall, computer attitude and computer anxiety were not indicative of dropping out. This result is not consistent with evidence from other studies (Hauser et al., 2012; Saadé \& Kira, 2009). In fact, our results are contrary to another recent similar study by Stiller and Köster (2016) showing large differences between dropout and persistent students groups. One reason for the null finding could be that these student characteristics interact with the type of learning materials, module performance tasks, and computer mediated communication. Stiller and Köster (2016) used instructional videos and transfer tasks (practical tasks) that are assumed to create a higher level of cognitive load given the transient nature of the presentation and the task difficulty. Learning activities and working on task solutions required the use of computers in their study, which when combined with negative attitudes and anxiety about the computer could lead to a higher cognitive load and even overload while learning, thus contributing to a student's decision to drop out. The student activities required in the studies of Hauser et al. (2012) and Saadé and Kira (2009) also included a more intensive use of computers combined with more complex computer mediated communication and learning activities, whereas studying in the present study was mainly reduced to working offline through a paper-based script (we assumed that most trainee teachers printed the pdf files) or an on-screen presentation of non-interactive illustrated texts and then assessing learning success via recognition tests (i.e., multiple-choice tests). Paperbased and on-screen scripts are assumed to create lower levels of cognitive load because of the stable nature of the presentation. Thus, the use of computers is not necessary or only a low level of interaction is required. Any negative attitudes or anxiety about the computer are not likely to contribute sufficiently to increase cognitive load to the point of influencing a learner's decision to drop out.

In general, dropping out continues to be a complex phenomenon. Dropout appeared at various stages in the online training, but the behaviour was not easily explained by the obtained quantitative data. The few effects found were small. Future studies should focus more on when dropping out occurs and the reasons behind it. In this study, we showed that some learner characteristics are connected to dropping out. We expect that these characteristics influence 
cognitive load, but we did not have load assessments of dropout groups. Hence, we could not relate these characteristics to cognitive load. Factors that lie outside an online learning experience such as family and job circumstances should be included in future analyses, especially for advanced, self-contained vocational training courses that are not integrated into a larger program. Identifying important variables at various critical stages of dropout that can be influenced by instructors might lead to more effective interventions to increase persistence and successful training outcomes. Our results suggest that learning management skills and domain-specific prior knowledge would be a good starting point when developing interventions against dropping out.

A special problem might arise when online trainings are free as in the current study. There are likely to be a wide range of motives that lead to course registration and participation. We can only assume that trainee teachers enrolled in the training were motivated to learn and to obtain a training certificate. Without identifying which students are really willing to study and to complete the course, we cannot target dropout interventions for those who are at risk. This variety of participating students might have also contributed to the difficulty of identifying relevant factors of dropout and to an underestimation of effects in this study. Online trainings that are integrated into a study program that must be completed to progress in that program (e.g., in many colleges or universities) might bring more participation and study pressure with it, so that the decision to drop out would have to be well grounded. This assumption might also apply to online trainings that require a fee.

\section{References}

1. Allen, I. E., \& Seaman, J. (2016). Online report card: Tracking online education in the United States. Babson Park, MA: Babson Research Group.

2. Amadieu, F., Tricot, A., \& Mariné, C. (2009). Exploratory study of relations between prior knowledge, comprehension, disorientation and on-line processes in hypertext. The Ergonomics Open Journal, 2, 49-57.

3. Bernard, R. M., Abrami, P.C., Lou, Y., Borokhovski, E., Wade, A., Wozney, L., Wallet, P.A., Fiset, M., \& Euan, B. (2004). How does distance education compare with classroom instruction? A meta-analysis of the empirical literature. Review of Educational Research, 74, 379439.

4. Castles, J. (2004). Persistence and the adult learner: Factors affecting persistence in Open University students. Active Learning in Higher Education, 5, 166-179.

5. Chyung, S. Y. (2001). Systematic and systemic approaches to reducing attrition rates in online higher education. American Journal of Distance Education, 15(3), 36-49.

6. Federal Ministry of Education and Research (2016). Education and Research in Figures 2016. Retrieved from https://www.bmbf.de/pub/Education_and_Research_in_Figures_2016.pdf

7. Friedrich, H. F., \& Mandl, H. (1992). Lern- und Denkstrategien - ein Problemaufriß. In H. Mandl \& H. F. Friedrich (Eds.), Lern- und Denkstrategien. Analyse und Intervention (pp. 3-54). Göttingen: Hogrefe.

8. Gagné, R. M., Briggs, L. J., \& Wager, W. W. (1992). Principles of instructional design. Belmont, CA: Wadsworth/Thomson Learning.

9. Gazza, E. A., \& Hunker, D. F. (2014). Facilitating student retention in online graduate nursing education programs: A review of the literature. Nurse Education Today, 34, 1125-1129.

10. Grau-Valldosera, J., \& Minguillón, J. (2014). Rethinking dropout in online higher education: The case of the Universitat Oberta de Catalunya. The International Review of Research in Open and Distributed Learning, 15(1), 290-308. 
11. Griese, B., Lehmann, M., \& Roesken-Winter, B. (2015). Refining questionnaire-based assessment of STEM students' learning strategies. International Journal of STEM Education, 2(12), $1-12$.

12. Hart, C. (2012). Factors associated with student persistence in an online program of study: A review of the literature. Journal of Interactive Online Learning, 11, 19-42.

13. Hartnett, M., St. George, A., \& Dron, J. (2011). Examining motivation in online distance learning environments: Complex, multifaceted and situation-dependent. The International Review of Research in Open and Distance Learning, 12(6), 20-38.

14. Hauser, R., Paul, R., \& Bradley, J. (2012). Computer self-efficacy, anxiety, and learning in online versus face to face medium. Journal of Information Technology Education: Research, 11, 141 154.

15. Holder, B. (2007). An investigation of hope, academics, environment, and motivation as predictors of persistence in higher education online programs. The Internet and Higher Education, 10, 245-260.

16. Ivankova, N. V., \& Stick, S. L. (2007). Students' persistence in a distributed doctoral program in educational leadership in higher education: A mixed methods study. Research in Higher Education, 48, 93-135.

17. Kalyuga, S., Ayres, P., Chandler, P., \& Sweller, J. (2003). The expertise reversal effect. Educational Psychologist, 38, 23-31.

18. Kalyuga, S. (2014). The expertise reversal principle in multimedia learning. In R. E. Mayer (Ed.), The Cambridge handbook of multimedia learning (pp. 576-597). New York, NY: Cambridge University Press.

19. Keller, J. M., \& Kopp, T. W. (1987). An application of the ARCS model of motivational design. In C. M. Reigeluth (Eds.), Instructional theories in action: Lessons illustrating selected theories and models (pp. 289-320). Hillsdale: Erlbaum.

20. Kember, D. (1989). A longitudinal-process model of drop-out from distance education. Journal of Higher Education, 60, 278-301.

21. Kranzow, J. (2013). Faculty leadership in online education: Structuring courses to impact student satisfaction and persistence. Journal of Online Learning and Teaching, 9, 131-139.

22. Lee, Y., \& Choi, J. (2011). A review of online course dropout research: Implications for practice and future research. Educational Technology Research and Development, 59, 593-618.

23. Lee, Y., Choi, J., \& Kim, T. (2013). Discriminating factors between completers of and dropouts from online learning courses. British Journal of Educational Technology, 44, 328-337.

24. Long, L., Dubois, C., \& Faley, R. (2009). A case study analysis of factors that influence attrition rates in voluntary online training programs. International Journal on E-Learning, 8, 347359.

25. McDonald, S., \& Stevenson, R. J. (1998). Effects of text structure and prior knowledge of the learner on navigation in hypertext. Human Factors, 40, 18-27.

26. Osborn, V. (2001). Identifying at-risk students in videoconferencing and web-based distance education. American Journal of Distance Education, 15(1), 41-54.

27. Park, J.-H., \& Choi, H. J. (2009). Factors influencing adult learners' decision to drop out or persist in online learning. Educational Technology \& Society, 12(4), 207-217.

28. Parker, A. (2003). Identifying predictors of academic persistence in distance education. United States Distance Learning Association Journal, 17(1), 55-61. 
29. Pintrich, P. R. (1999). The role of motivation in promoting and sustaining self-regulated learning. International Journal of Educational Research, 31, 459-470.

30. Reinmann, G., \& Mandl, H. (2006). Unterrichten und Lernumgebungen gestalten. In A. Krapp \& B. Weidenmann (Eds.), Pädagogische Psychologie. Ein Lebrbuch (pp. 613-658). Weinheim: Beltz.

31. Richter, T., Naumann, J., \& Groeben, N. (2000). Attitudes toward the computer: Construct validation of an instrument with scales differentiated by content. Computers in Human Behavior, $16,473-491$.

32. Richter, T., Naumann, J. \& Horz, H. (2010). Eine revidierte Fassung des Inventars zur Computerbildung (INCOBI-R). Zeitschrift für Pädagogische Psychologie, 24, 23-37.

33. Ryan, R. M. (1982). Control and information in the intrapersonal sphere: An extension of cognitive evaluation theory. Joumal of Personality and Social Psychology, 43, 450-461.

34. Ryan, R. M., \& Deci, E. L. (2000). Intrinsic and extrinsic motivations: Classic definitions and new directions. Contemporary Educational Psychology, 25, 54-67.

35. Saadé, R. G., \& Kira, D. (2009). Computer anxiety in e-learning: The effect of computer selfefficacy. Journal of Information Technology Education: Research, 8, 177-191.

36. Sam, H. K., Othman, A. E. A., \& Nordin, Z. S. (2005). Computer self-efficacy, computer anxiety, and attitudes toward the internet: A study among undergraduates in Unimas. Educational Technology \& Society, 8(4), 205-219.

37. Shin, N., \& Kim, J. (1999). An exploration of learner progress and drop-out in Korea National Open University. Distance Education, 20, 81-95.

38. Stiller, K. (2003). Lernstrategien und Lernerfolg beim computerbasierten Wissenserwerb. Psychologie in Erziehung und Unterricht, 50, 258-269.

39. Stiller, K. D. (2009). Mono- und bimodale Textpräsentationen zu Bildern in HypermediaSystemen. Psychologie in Erziehung und Unterricht, 56, 49-63.

40. Stiller, K. D. (2015a). Linear vs. pictorial access to on-screen text and computer attitude. In S. Carliner, C. Fulford, \& N. Ostashewski (Eds.), Proceedings of EdMedia: World Conference on Educational Media and Technology 2015 (pp. 158-167). Chesapeake, VA: AACE.

41. Stiller, K. D. (2015b). Promoting computerized learning via pictorial access to on-screen text. In S. Carliner, C. Fulford, \& N. Ostashewski (Eds.), Proceedings of EdMedia: World Conference on Educational Media and Technology 2015 (pp. 59-68). Chesapeake, VA: AACE.

42. Stiller, K. D., \& Köster, A. (2016). Learner attrition in an advanced vocational online training: The role of e-learning experience, computer attitude, and computer anxiety. European Journal of Open, Distance and E-Learning, 19(2), 1-14.

43. Stiller, K. D., \& Köster, A. (submitted). Cognitive loads and training success in a video-based online training course.

44. Sweller, J. (2010). Element interactivity and intrinsic, extraneous, and germane cognitive load. Educational Psychology Review, 22, 123-138.

45. Tinto, V. (1993). Leaving college: Rethinking the causes and cures of student attrition. Chicago: The University of Chicago Press.

46. Tomei, L. A. (2007). A theoretical model for designing online education in support of lifelong learning. In Y. Inoue (Eds.), Online education for lifelong learning (pp. 122-145). Hershey: Information Science Publishing. 
47. Tyler-Smith, K. (2006). Early attrition among first time eLearners: A review of factors that contribute to drop-out, withdrawal and non-completion rates of adult learners undertaking eLearning programmes. Journal of Online Learning and Teaching, 2, 73-85.

48. Weinstein, C. E., \& Mayer, R. E. (1986). The teaching of learning strategies. In M. C. Wittrock (Ed.), Handbook of research on teaching: Third edition (pp. 315-327). New York, NY: Macmillan.

49. Wild, K.-P., \& Schiefele, U. (1994). Lernstrategien im Studium: Ergebnisse zur Faktorenstruktur und Reliabilität eines neuen Fragebogens. Zeitschrift für Differentielle und Diagnostische Psychologie, 15, 185-200.

50. Xenos, M., Pierrakeas, C., \& Pintelas, P. (2002). A survey on student dropout rates and dropout causes concerning the students in the course of informatics of the Hellenic Open University. Computers \& Education, 39, 361-377.

51. Yukselturk, E., \& Bulut, S. (2007). Predictors for student success in an online course. Educational Technology \& Society, 10(2), 71-83. 


\section{Appendix}

Table A: Items assessing intrinsic motivation, computer attitude and computer anxiety were rated on five-point Likert scales from do not agree to agree

Intrinsic motivation (scale "Interest / Enjoyment" by Ryan et al., 1982; authors' translation)

$1 \quad$ I think I will enjoy studying the modules very much.

2 I think studying the modules will be fun to do.

3 I think studying the modules will be a boring activity.

$4 \quad$ I think studying the modules will not hold my attention at all.

5 I think studying the modules will be very interesting.

6 I think this activity will be quite enjoyable.

7 I think I will not enjoyed studying the modules.

Computer attitude (scale "Personal experience / learning and working / autonomous entity" by Richter et al., 2010)

1 To me, the computer seems too unreliable to use as a learning tool.

2 I am often frustrated by the fact that the computer simply does not make sense to ordinary people.

3 When I use the computer for work, I constantly worry that it might break down.

$4 \quad$ Working with the computer is often frustrating because I do not understand the machine.

5 Sometimes my computer does things I do not understand.

6 The computer programs that I use for learning and working are sometimes hard to understand.

7 When I work with a computer, I feel that the computer does what it wants.

8 If I have computer problems while I am working, I feel helpless.

$9 \quad$ I wish I had to work less with computers.

Computer anxiety (scale "Confidence in dealing with computers and computer applications" by Richter et al., 2010)

1 I feel confident in using the computer.

2 I panic when my computer crashes.

3 In working with the computer, I am easily frustrated when problems occur.

$4 \quad$ Working with the computer makes me uneasy.

5 When working with the computer, I am often worried that I might break something.

6 I feel that I cannot really control my computer.

7 If possible, I avoid working with the computer.

8 In the case of occurring computer problems, I stay calm.

Table B: Items assessing learning skills were rated on five-point Likert scales from very rarely to very often

Meta-cognitive strategies (Griese et al., 2015); $(p)=$ planning, $(m)=$ monitoring, $(r)=$ regulating

1 I try to consider beforehand which areas of certain topics I have to study and which I do not have to study.(p)

2 Confronted with a difficult subject matter I adapt my learning strategy accordingly.( $r$ )

3 If I do not understand everything I am reading, I will try to make a note of the gap in my knowledge and sift through the material again.( $r$ )

4 I decide in advance how much subject matter I would like to work through in this session.(p)

5 Before starting on an area of expertise, I reflect upon how to work most efficiently. (p)

6 I plan in advance in which order I want to work through the subject matter.(p)

7 I ask myself questions on the subject matter in order to make sure that I have understood everything correctly. $(\mathrm{m})$

8 In order to find gaps in my knowledge I sum up the most important contents without using my notes. $(\mathrm{m})$ 
9 I work on additional tasks in order to determine if I have truly understood the subject matter. $(\mathrm{m})$

10 In order to check my own understanding I explain certain parts of the subject matter to a fellow student.(m)

11 When an aspect seems confusing or unclear, I examine it again thoroughly.( $r$ )

Time management (Griese et al., 2015)

1 I work according to a schedule.

2 I decide on the times for my learning.

3 I fix the hours I spend daily on learning in a schedule.

$4 \quad$ Before each study period I appoint the duration of my work.

Learning environment (Griese et al., 2015)

1 I work in a place that makes it easy to concentrate.

2 I design my work environment in a way that I am distracted as little as possible.

3 When learning I always sit at the same place.

$4 \quad$ When studying I make sure that I can work uninterrupted.

5 My workplace is designed in a way that makes it easy to find everything.

6 At my desk I have the most important papers within reach. 